\title{
China-U.S. Trade Frictions, Opinion Divergence, and Stock Volatilities
}

\author{
Wenjia Zhang ${ }^{1}$ \\ ${ }^{1}$ School of International Economics, China Foreign Affairs University, Beijing, China \\ Correspondence: Wenjia Zhang, School of International Economics, China Foreign Affairs University, No. 24, \\ Zhanlan Road, Xicheng District, Beijing, 100037, China. E-mail: wzhang@cfau.edu.cn
}

Received: March 31, 2021

Accepted: April 28, 2021

Online Published: May 10, 2021

doi:10.5539/ijef.v13n6p19

URL: https://doi.org/10.5539/ijef.v13n6p19

\begin{abstract}
China-US economic relation is of particular significance to the world economy. This paper aims to investigate how trade frictions influence Chinese stock market volatilities. Overall, trade frictions significantly increase large stocks' volatilities, whereas influences the SMEs differently before and after the 301 investigation. For the big caps (SSE50), opinion divergence has a partial mediation effect between trade frictions and market volatilities. Trade frictions lead to higher opinion divergence, and opinion divergence reduces market volatility before the 301 investigation and increases market volatility in Stages IV and V. This result is robust after controlling the endogeneity of opinion divergence. For the small caps (SMEs), the mediation effect has not been detected, but opinion divergence significantly influences stock volatility, negative before the Section 301 investigation, whereas positive after that.
\end{abstract}

Keywords: opinion divergence, volatility, China-US trade frictions

\section{Introduction}

Since the 1980s, it has become increasingly clear that traditional asset-pricing models, such as the CAPM model of Sharpe (1964) and APT model of Ross (1976), have a hard time explaining the growing number of market anomalies discovered by financial scholars. However, these anomalies have been supported by psychological theories and experimental research results (Hong \& Stein, 1999). It is referred to as the bounded-rationality framework, under which the deviations from efficient prices can persist (Delong et al., 1990; Shleifer \& Vishny, 1997). One important reason is that investor sentiment movements are in part unpredictable, leading to limited arbitrage; therefore, investor sentiment becomes more extreme, and prices move even further away from the fundamental value (Barberis, Shleifer, \& Vishny, 1998).

As an emerging market, China has a stock market characterized by high volatility, partly because the market participants are mainly individual investors and the limited margin trading business limits their arbitrage ability. In our impression, with the escalation of US-China trade frictions, the market went up and down considerably. Almost at each time when a piece of trade war news was released, the stock market plummeted and also rose sharply on a few occasions. For example, the market went up sharply on June 19, 2019, after President Xi and President Trump spoke on the phone the day before.

The efficient market theory asserts that there is no cost of getting information, and investors have homogeneous expectations. However, in practice, investors have differing estimates of the returns from investing in risky securities (Miller, 1977). Even if individuals possess the same information, they may differ in their interpretation of this information and consequently hold different beliefs. And differences in the beliefs of investors may be the source of the apparent "excess volatility" (Hong \& Stein, 2007).

The state-controlled media has been questioned in terms of operating efficiency and independence, for the self-censorship undermines the quality of news articles published by the state-controlled media, particularly when their coverage is entangled with political interests (Djankov et al., 2003; Besley \& Prat, 2006; Houston, Lin, \& Ma, 2011; Dyck, Moss, \& Zingales, 2013). As the receiver and interpreter of information mainly came from the state-controlled media, China's investors would tend to have divergent opinions on the prospects of the US-China trade war, for most news was temporary and subject to many uncertainties as well.

This research is aimed at investigating the relationship between China-US trade frictions and Chinese stock 
market volatilities and the role opinion divergence plays during this process. Firstly, we find that trade frictions significantly increase the volatilities of large stocks, whereas they influence the SMEs differently before and after the 301 investigation. Secondly, for the big caps (SSE50), opinion divergence had a partial mediation effect between trade frictions and market volatilities, where trade frictions lead to higher opinion divergence, and opinion divergence reduces market volatility before the 301 investigation but increases market volatility in Stages IV and V. Thirdly, the result of SSE50 is robust after controlling the endogeneity of opinion divergence. Lastly, for the small caps (SMEs), a mediation effect has not been found, but opinion divergence significantly influences stock volatility, negative before the Section 301 investigation whereas positive after that.

Although traditional newspapers, like People's Daily, provide prompt information on the latest incidents and direct viewpoints of the government and are bound to influence the stock market, their effects on the stock market have been seldom investigated. This research contributes to the literature that analyzes how the bilateral relations in terms of China-U.S. trade frictions influence the stock market and explains how the market interprets the state-controlled news. The market reactions to trade friction news are also examined during different phases and on different stocks groups.

This study also contributes to the literature that analyzes the sources, patterns, and effects of opinion divergence. We are the first to identify the asymmetric mediation effect of opinion divergence in the relation between trade friction news and market volatility.

We further contribute to the literature by disentangling the relations between news releasing, opinion divergence, and stock market fluctuations. Literature shows that external factors, such as natural disaster (Kaplanski \& Levy, 2010), major international sports events (Edmans, Garcia, \& Norli, 2007; Kaplanski \& Levy, 2010), and weather (Hirshleifer \& Shumway, 2003; Cao \& Wei, 2005; Goetzmann et al., 2015), may bring about negative emotions and anxieties of investors and therefore influence their investment decisions. However, the sentiment about trade frictions comes into shape and is transmitted has not been investigated. Our result provides one possible explanation for this issue.

The rest of the paper proceeds as follows. Section 2 develops hypotheses based on related literature. Section 3 describes the methodological design and data. Section 4 reports and discusses the empirical results. Section 5 concludes.

\section{Literature Review and Hypotheses Development}

Literature has shown that the stock market volatilities are related to some incidents, such as political events (Note 1), natural disasters (Note 2), and industrial disasters (Note 3), etc.. Historical experience tells us that bilateral friction is an important event that drives the emotional fluctuation in the securities market, which has been seldom touched in academic literature.

China and the United States have a long history of disputes over intellectual property rights. In 1990, China was included in the "priority watch list" of the United States. And the United States has used section 301 six times against China since April 1991 (Note 4). Since Donald Trump's inauguration, investors have perceived more uncertainties, fearing that China and the U.S. would enter the Thucydides trap (Note 5) or even into the "new cold war". The spread of this sentiment has become a significant force affecting the volatility of the stock market.

Donald Trump, who already publicly expressed his unfriendliness to China (Note 6), announced his candidacy for U.S. President on June 16, 2015. In November 2015, he promised to designate China as a currency manipulator on his first day in office (Note 7). In January 2016, he further proposed a 45 percent tariff on Chinese exports to the United States (Note 8). As expressed by Navarro and Ross (2016), the Trump campaign economic policy prioritized "eliminating America's chronic trade deficit," particularly with China. In 2018, a trade war was finally launched by the United States against China for various reasons.

As the global economic growth slowed down (Note 9), the effect of tensions between China and the U.S. on the global economy is expected to be drastically amplified. A simple association between media activity and stock market activity (volatility) may result from news shocks, which create an omitted variable bias (Peress, 2014). Therefore, China-US trade negotiations/frictions could be crucial issues that influence investors' expectations and prompt actions on the market. It also would be of particular significance to study investor behaviors in such an emerging capital market, where there may be different sources and patterns of emotionally driven price movements. Specifically, we assume,

H1: Each time the trade-friction news is released, the market perceives more risks and leads to higher volatility.

News media is critical in interpreting and disseminating updated news about specific events that might influence 
the whole economy/market, such as bilateral trade frictions. They "do play an important role both in setting the stage for market moves and in instigating the moves themselves" (Shiller, 2005). Lamla and Maag (2012) found a significant impact of news stories (tone) coverage on disagreement in households' inflation forecasts. When their coverage is entangled with political interests (e.g., Houston, Lin, \& Ma, 2011; Dyck, Moss, \& Zingales, 2013), investors tend to have divergent opinions on the prospects of the US-China trade war.

According to Hong and Stein (2007) and Duchin and Levy (2010), changes in disagreement may lead to apparent "excess volatility", which holds at the level of the individual stock, as well as at the market level. However, according to Lakonishok, Shleifer, and Vishny (1992), Christie and Huang (1995), Nofsinger and Sias (1999), disagreement about future earnings reduces stock volatility, whereas herding increases stock volatility. The correlation between investors' expectations of future returns is similar to the mechanism of herding behavior. The smaller the divergence between investors on future earnings, the more likely they will trade in the same direction, making asset prices more likely to rise or fall rapidly, thereby increasing market volatility.

So, a priori relation between opinion divergence and stock volatility is unclear, and in different stages, people truly might predict the likelihood of the war differently. Early on, most people did not believe that the U.S. would dare to have a trade war since China's exports benefited U.S. consumers so much. How would the U.S. have a trade war at the expense of economic interests? During these early days of the trade war, i.e., stage IV (see Appendix A), China's financial market's general view was that the trade war threat between China and the United States was just "cheap talk". Later on May 20, China and the United States agreed to put the trade war on hold after China reportedly agreed to buy more U.S. goods. However, on May 29, the U.S. reinstated tariff plans after a brief truce (Note 10). As China and the U.S. formally promised that tariffs would be imposed sometime later, the market seemed to quickly realize that the early views were Utopian and the trade war was a severe threat to both. The market declined dramatically, especially when the two tariffs landed in the China-US trade war in July 2018. Trump and Chinese President Xi Jinping agreed on a temporary stop to their bilateral trade disagreement on December 1, 2018 (Note 11). However, the stock market did not respond positively. With the global economic slowdown, major stock markets experienced the worst year in 2018. The truce did not seem to be enough to change Chinese investors' negative judgments about prospects, although the Chinese official media were pretty optimistic about the ceasefire.

After Trump's inauguration, especially the periods in which the China-US trade frictions were escalated, investors would be very sensitive (alert) and even skeptical about what was happening, and interpret it in different ways and show disagreement of opinion, which would lead to higher volatilities. It is consistent with the idea that higher volatility in the securities market is always associated with a higher informational asymmetry (Illeditsch, 2011). Also, the news release might reflect the Chinese government's attitude or resolve not to compromise. How would the investors interpret such news? Would they reach consent? So, we assume the state-controlled media played a role in bringing about disagreement among investors, thereby leading to some effect on the stock market. Specifically, we assume that:

H2: Releasing news related to the China-US trade frictions from state-controlled media leads to a higher opinion divergence.

\section{H3: Opinion divergence is the mediator between news releasing and stock volatility.}

The entire Trump era is divided into several stages based on key events (see Appendix A). At each stage, investors might interpret and react differently to the news. Therefore, we investigate the same hypothesis in different sub-periods.

\section{Data and Methodology}

\subsection{Data Sources}

Our research sample starts from June 16, 2015, when Donald Trump announced his candidacy for the President of the United States of America at Trump Tower in Manhattan, and extends to March 31, 2019. The daily volatilities of the SSE50 Index of the Shanghai Stock Exchange are extracted from RESSET database.

Given that most of the world's population receives information from the state-controlled media(Karlekar \& Dunham, 2014), media outlets controlled by the government, we take reference on relevant studies (Li \& Shen, 2010; You \& Wu, 2012; Wang \& Wu, 2015). All the news related to U.S.-China trade frictions is taken from "Seven Newspapers and One Journal" (Note 12) and People's Daily, either from their official website or from the Genius Finance database June 2015 to September 2018, totaling 143 articles. 


\subsection{Measuring Opinion Divergence}

Several studies have adopted either turnovers or standardized volumes as the proxy for opinion divergence for individual stocks (Shalen, 1993; Jones \& Lammont, 2002; Chang, 2007; Garfinkel \& Sokobin, 2006; and Demirkan, 2012, etc.). We followed Garfinkel and Sokobin (2006) and Demirkan (2012) and used unexpected turnovers (standardized volumes) on specific dates as our proxy variable for opinion detergence (Note 13). Instead of looking at the opinion divergence around specific events for individual firms, we investigated the entire market.

Specifically, we began by extracting daily turnovers of SSE50 from iFind database. The unexpected turnover of news releasing day is measured with the average daily market-adjusted turnover across the formation date window $(t-1, t)$, where day $t$ is the investigated day.

$$
\Delta \mathrm{TO}_{\mathrm{t}}=\mathrm{TO}_{\mathrm{t}}-\frac{\sum_{\mathrm{i}=-54}^{-5} \mathrm{TO}_{\mathrm{i}}}{50}
$$

$\mathrm{TO}_{\mathrm{t}}$ is the turnover for SSE50 components on day t. Turnover may capture not only volume attributable to divergent opinions but also include liquidity trading. In other words, the liquidity aspect of $\mathrm{TO}_{t}$ is adjusted by subtracting the average turnover over the previous quarter $(\mathrm{t}-54, \mathrm{t}-5)$.

\subsection{Baseline Model}

Regressions are conducted on the daily volatilities of the SSE 50 Index (or SME index), with Trade Friction as the key variables and controls added.

$$
\text { Volatility of SEE50 }=\alpha+\beta_{0} * \text { Trade Friction }+\Sigma \beta_{i} * \text { CONTROL }+\varepsilon_{i}
$$

"Trade Friction" is a dummy variable, which equals 1 when any of the People's Daily and the other eight major financial and economic media outlets carry articles on China-US trade friction issues on day $\mathrm{t}$, and 0 otherwise. Macroeconomic variables, like long-term interest rates (Yardeni, 1997, 1999; Greenspan, 2007; Humpe and Macmillan, 2009). We included the interest rate changes based on the long-term interest rate (e.g., a 10-year bond yield) (Note 14) to control this effect. The exchange rate could be another influencing factor (Mukherjee \& Naka, 1995; Maysami \& Koh, 2000). Compared with Maysami and Koh (2000) and Eun and Resnick (1984), who claim that using monthly data led to a more robust estimate, we use daily data (Note 15) to better depict the volatile nature of stock prices. Economic Prospect and Consumer Confidence are also included to control the possible fundamental economic conditions. Regressions are conducted on both the entire period and different stages.

\subsection{Model Testing Mediation Effects of Opinion Divergence}

To further test whether news releasing on trade frictions influences stock market volatility via opinion divergence, we followed the method of Baron and Kenny (1986) and constructed the mediation model (1) (3).

$$
\begin{aligned}
& \text { Opinion Divergence }=\alpha+\beta_{0}{ }^{\prime} * \text { Trade Friction }+\Sigma \beta_{i}{ }^{\prime} * \text { CONTROL }+\varepsilon_{i} \\
& \text { Volatility of SEE50 }=\alpha+\beta_{0}{ }^{\prime \prime} * \text { Opinion Divergence }+\beta_{1}{ }^{\prime \prime} * \text { Trade Friction }+\Sigma \beta_{i}{ }^{\prime \prime} * \text { CONTROL }+\varepsilon_{i}
\end{aligned}
$$

Equation (2) examined the relationship between news releasing and opinion divergence. In equation (3), Trade Friction is the explanatory variable, and Opinion Divergence is the mediator. In equation (1), $\beta_{0}$ shows the total effect of Trade Friction on market volatility. And in equation (2), $\beta_{0}{ }^{\prime}$ shows impact of Trade Friction on Opinion Divergence. And in equation (3), $\beta_{1}$ " shows impact of Trade Friction after controlling the mediator Opinion Divergence, and $\beta_{0}$ " shows the indirect effect of Opinion Divergence after controlling Trade Friction. Specifically, if $\beta_{0}$ in equation (1), $\beta_{0}{ }^{\prime}$ in equation (2), and $\beta_{0}{ }^{\prime \prime}$ in equation (3) are all significant, the mediation effect is substantial. With these equations, we can test the influencing path of news releasing on market volatility.

\section{Empirical Results}

Table 1 reports the descriptive statistics of key variables in our analysis. Panel A shows that all variables are stable based on ADF tests. Panel B presents correlations between these variables. Most variables are uncorrelated, except for "Change of Economic Prospect" to "Change of Consumer Confidence". We orthogonalize "Change of Economic Prospect" to "Change of Consumer Confidence" and used the orthogonalized variable in the following regressions. 
Table 1. Descriptive statistics

Panel A: Statistics of Individual Variables

\begin{tabular}{cccccc}
\hline & Trade Friction & $\begin{array}{c}\text { Change 10-year } \\
\text { Bond Yield (\%) }\end{array}$ & $\begin{array}{c}\text { \% Change of } \\
\text { Exchange Rate }\end{array}$ & $\begin{array}{c}\text { Change of Economic } \\
\text { Prospect }\end{array}$ & $\begin{array}{c}\text { Change of Consumer } \\
\text { Confidence }\end{array}$ \\
\hline Mean & 0.145 & -0.005 & 0.009 & 0.003 & 0.020 \\
Median & 0.000 & 0.000 & 0.000 & 0.000 & 0.000 \\
Maximum & 1.000 & 3.190 & 1.860 & 4.568 & 5.300 \\
Minimum & 0.000 & -3.100 & -1.180 & -0.621 & -4.700 \\
Std. Dev. & 0.352 & 0.657 & 0.244 & 0.163 & -30.324 \\
ADF test & -6.145 & -22.693 & -28.695 & 0.000 & -30.374 \\
Probability & 0.000 & 0.000 & 0.000 & 922 & 0.000 \\
Observations & 926 & 926 & 926 & & 922 \\
\hline
\end{tabular}

Panel B: Correlations between Variables

\begin{tabular}{|c|c|c|c|c|c|}
\hline & Trade Friction & $\begin{array}{c}\text { Change of 10-year } \\
\text { Bond Yield }\end{array}$ & $\begin{array}{l}\% \text { Change of Exchang } \epsilon \\
\text { Rate }\end{array}$ & $\begin{array}{c}\text { Change of Economic } \\
\text { Prospect }\end{array}$ & $\begin{array}{c}\text { Change of Consumer } \\
\text { Confidence }\end{array}$ \\
\hline Trade Friction $(t)$ & 1 & & & & \\
\hline Change of 10-year Bond Yield & -0.052 & 1 & & & \\
\hline$\%$ Change of Exchange Rate & -0.041 & -0.025 & 1 & & \\
\hline Change of Economic Prospect & -0.031 & 0.029 & 0.003 & 1 & \\
\hline Change of Consumer Confidence & 0.025 & 0.022 & 0.038 & $0.076^{* *}$ & 1 \\
\hline
\end{tabular}

Note. This table reports the descriptive statistics of key variables in our analysis. The "Trade Friction" is a dummy variable, which equals 1 when any of the People's Daily and the other eight major financial and economic media carries articles on China-US trade frictions on day t. "Change of 10-year Bond Yield" equals the 10-year Treasury Bond Yield of the secondary market in day t minus that in day t-1. "Change of Exchange Rate" is the percentage change of the daily exchange rate (direct pricing method), where the positive number represents the depreciation of the RMB, and the percentage sign is omitted. Our sample covers the period from June 16, 2015, to March 31, 2019. "Change of Economic Prospect" is the "Economic Prospect Index", composed by the Nation Bureau of Statistics, in day t minus that in day t-1; "Change of Consumer Confidence" is the "Consumer Confidence Index" in day t minus that in day $\mathrm{t}-1$. Both are extracted from Genius Database. *, **, *** denote statistical significance at the 10,5 , and $1 \%$ levels, respectively, using a two-tailed test.

\subsection{Trade Frictions and Stock Market Volatilities}

Table 2 reports the regressions on the volatilities of SSE50 derived using the GARCH model. As shown in Panel $2 \mathrm{~A}$, news releasing on trade frictions significantly increases the stock volatility for the whole Trump era. When we look at different stages, the coefficients become insignificant in stages I, V, and VI due to sample reduction. In stages II, III, and IV, the coefficients are still significantly positive.

Table 2. The mediation effect of opinion divergence on the volatility of SSE50

Panel A:

\begin{tabular}{|c|c|c|c|c|c|c|c|c|c|}
\hline & \multicolumn{3}{|c|}{$\begin{array}{c}\text { (1) The Whole Trump Era (Since June } \\
\text { 16, 2015 - March 31, 2019) }\end{array}$} & \multicolumn{3}{|c|}{$\begin{array}{c}\text { (2) Before the Section } 301 \\
\text { Investigation (June 16, } 2015 \text { - } \\
\text { August 17, 2017) }\end{array}$} & \multicolumn{3}{|c|}{$\begin{array}{c}\text { (3) Since the Section } 301 \\
\text { Investigation (August 18, } 2017- \\
\text { March 31, 2019) }\end{array}$} \\
\hline & $\begin{array}{l}\text { Volatility of } \\
\text { SSE50 (\%) }\end{array}$ & $\begin{array}{c}\text { SSE50_UT } \\
\text { O }\end{array}$ & $\begin{array}{l}\text { Volatility of } \\
\text { SSE50 (\%) }\end{array}$ & $\begin{array}{l}\text { Volatility of } \\
\text { SSE50 (\%) }\end{array}$ & $\begin{array}{l}\text { SSE50_U } \\
\text { TO }\end{array}$ & $\begin{array}{l}\text { Volatility of } \\
\text { SSE50 (\%) }\end{array}$ & $\begin{array}{l}\text { Volatility of } \\
\text { SSE50 (\%) }\end{array}$ & $\begin{array}{l}\text { SSE50_U } \\
\text { TO }\end{array}$ & $\begin{array}{l}\text { Volatility of } \\
\text { SSE50 (\%) }\end{array}$ \\
\hline Intercept & $\begin{array}{l}1.401 * * * \\
{[48.966]}\end{array}$ & $\begin{array}{c}-0.037 * * * \\
{[-6.303]}\end{array}$ & $\begin{array}{l}1.365^{* * * *} \\
{[47.639]}\end{array}$ & $\begin{array}{l}1.543 * * * \\
{[34.577]}\end{array}$ & $\begin{array}{c}-0.059 * * * \\
{[-6.528]}\end{array}$ & $\begin{array}{c}1.4819 * * * \\
{[32.632]}\end{array}$ & $\begin{array}{l}1.173 * * * \\
{[58.262]}\end{array}$ & $\begin{array}{c}-0.001 \\
{[-0.141]}\end{array}$ & $\begin{array}{c}1.1732 * * * \\
{[58.475]}\end{array}$ \\
\hline $\begin{array}{l}\text { Opinion Divergence } \\
\text { (SSE50_UTO) }\end{array}$ & & & $\begin{array}{c}-0.971 * * * \\
{[-6.160]}\end{array}$ & & & $\begin{array}{c}-1.040 * * * \\
{[-4.903]}\end{array}$ & & & $\begin{array}{c}0.3462^{*} \\
{[1.911]}\end{array}$ \\
\hline Trade Friction $(t)$ & $\begin{array}{c}0.197 * * * \\
{[2.618]}\end{array}$ & $\begin{array}{c}0.074 * * * \\
{[4.803]}\end{array}$ & $\begin{array}{c}0.269^{* * *} \\
{[3.602]}\end{array}$ & $\begin{array}{l}0.369 * * \\
{[2.222]}\end{array}$ & $\begin{array}{c}0.088^{* * * *} \\
{[2.638]}\end{array}$ & $\begin{array}{c}0.461 * * * \\
{[2.816]}\end{array}$ & $\begin{array}{c}0.315^{* * *} \\
{[7.770]}\end{array}$ & $\begin{array}{c}0.042 * * * \\
{[3.727]}\end{array}$ & $\begin{array}{c}0.3003 * * * \\
{[7.303]}\end{array}$ \\
\hline $\begin{array}{l}\text { Change 10-year Bond } \\
\text { Yield }\end{array}$ & $\begin{array}{c}-9.465^{* *} \\
{[-2.351]}\end{array}$ & $\begin{array}{l}1.405^{*} \\
{[1.699]}\end{array}$ & $\begin{array}{l}-8.101 * * \\
{[-2.049]}\end{array}$ & $\begin{array}{c}-15.121 * * \\
{[-2.492]}\end{array}$ & $\begin{array}{c}1.157 \\
{[0.947]}\end{array}$ & $\begin{array}{c}-13.918 * * \\
{[-2.342]}\end{array}$ & $\begin{array}{c}2.097 \\
{[0.699]}\end{array}$ & $\begin{array}{l}1.800 * * \\
{[2.140]}\end{array}$ & $\begin{array}{l}1.4738 \\
{[0.490]}\end{array}$ \\
\hline $\begin{array}{l}\% \text { Change of } \\
\text { Exchange Rate }\end{array}$ & $\begin{array}{c}9.578 \\
{[0.883]}\end{array}$ & $\begin{array}{l}-4.014^{*} \\
{[-1.802]}\end{array}$ & $\begin{array}{c}5.679 \\
{[0.533]}\end{array}$ & $\begin{array}{c}-1.755 \\
{[-0.087]}\end{array}$ & $\begin{array}{c}-3.376 \\
{[-0.832]}\end{array}$ & $\begin{array}{c}-5.267 \\
{[-0.267]}\end{array}$ & $\begin{array}{c}14.867 * * \\
{[2.381]}\end{array}$ & $\begin{array}{c}-3.594 * * \\
{[-2.053]}\end{array}$ & $\begin{array}{c}16.111 * * \\
{[2.575]}\end{array}$ \\
\hline Change of Economic & -0.127 & 0.006 & -0.121 & -0.211 & 0.006 & -0.205 & 0.240 & 0.071 & 0.2151 \\
\hline Prospect & {$[-0.783]$} & [0.192] & {$[-0.759]$} & {$[-0.999]$} & {$[0.133]$} & {$[-0.992]$} & [0.885] & [0.932] & [0.796] \\
\hline Change of Consumer & -0.054 & 0.002 & -0.052 & -0.07 & 0.012 & -0.07 & -0.019 & -0.003 & -0.018 \\
\hline Confidence & {$[-0.944]$} & {$[0.211]$} & {$[-0.920]$} & {$[-0.667]$} & [0.577] & {$[-0.558]$} & {$[-0.501]$} & {$[-0.251]$} & {$[-0.479]$} \\
\hline Adjusted R-squared & 0.011 & 0.026 & 0.05 & 0.016 & 0.007 & 0.057 & 0.132 & 0.050 & 0.138 \\
\hline $\mathrm{n}$ & 922 & 922 & 922 & 531 & 531 & 531 & 391 & 391 & 391 \\
\hline Akaike info criterion & 2.403 & -0.762 & 2.365 & 2.82 & -0.386 & -6.432 & 0.714 & -1.829 & -8.500 \\
\hline
\end{tabular}


Panel B:

(1) Before Trump's Inauguration (June 16,2015 - Jan 19, 2017)
(2) Trump's Inauguration till the Section (3) The Early Stage Of China-U.S. 301 Investigation (Jan 20, 2017 - Aug Trade Friction (Aug 18, 2017 - Mar 7, 17, 2017)

\begin{tabular}{|c|c|c|c|c|c|c|c|c|c|}
\hline & & & & & & & & & \\
\hline & $\begin{array}{l}\text { Volatility of } \\
\text { SSE50 (\%) }\end{array}$ & SSE50_UTO & $\begin{array}{l}\text { Volatility of } \\
\text { SSE50 }(\%)\end{array}$ & $\begin{array}{l}\text { Volatility of } \\
\text { SSE50 (\%) }\end{array}$ & SSE50_UTO & $\begin{array}{l}\text { Volatility of } \\
\text { SSE50 }(\%)\end{array}$ & $\begin{array}{l}\text { Volatility of } \\
\text { SSE50 (\%) }\end{array}$ & SSE50_UTO & $\begin{array}{l}\text { Volatility of } \\
\text { SSE50 (\%) }\end{array}$ \\
\hline \multirow[t]{2}{*}{ Intercept } & $1.782 * * *$ & $-0.068 * * *$ & $0.017 * * *$ & $0.808 * * *$ & $-0.030 * * *$ & $0.8129 * * *$ & $0.927 * * *$ & $0.011 *$ & $0.9229 * * *$ \\
\hline & {$[32.655]$} & {$[-5.647]$} & [30.881] & {$[53.566]$} & {$[-5.876]$} & [47.962] & {$[58.553]$} & [1.696] & [58.016] \\
\hline Opinion Divergence & & & $-0.009 * * *$ & & & 0.166 & & & 0.351 \\
\hline (SSE50_UTO) & & & {$[-4.014]$} & & & {$[0.659]$} & & & {$[1.597]$} \\
\hline \multirow[t]{2}{*}{ Trade Friction $(t)$} & -0.174 & 0.082 & -0.001 & $1.397 * * *$ & $0.069 * * *$ & $1.3855 * * *$ & $0.718 * * *$ & 0.003 & $0.717 * * *$ \\
\hline & {$[-0.690]$} & [1.484] & {$[-0.398]$} & {$[35.343]$} & {$[5.112]$} & [31.996] & {$[10.516]$} & [0.112] & {$[10.564]$} \\
\hline Change 10-year & $-14.134^{*}$ & 1.589 & $-0.127 *$ & $-3.232 *$ & -0.526 & -3.144 & -5.111 & 1.671 & $-5.697 *$ \\
\hline Bond Yield & {$[-1.884]$} & {$[0.966]$} & {$[-1.721]$} & {$[-1.665]$} & {$[-0.790]$} & {$[-1.612]$} & {$[-1.635]$} & {$[1.330]$} & {$[-1.821]$} \\
\hline$\%$ Change of & -18.971 & -2.958 & -0.217 & -8.013 & -2.298 & -7.631 & -9.237 & $-6.290 * *$ & -7.032 \\
\hline Exchange Rate & {$[-0.778]$} & {$[-0.553]$} & {$[-0.906]$} & {$[-1.133]$} & {$[-0.947]$} & {$[-1.073]$} & {$[-1.424]$} & {$[-2.413]$} & {$[-1.066]$} \\
\hline Change of Economic & -0.265 & 0.009 & -0.003 & 0.320 & -0.218 & 0.357 & 0.287 & 0.011 & 0.283 \\
\hline Prospect & {$[-1.177]$} & [0.187] & {$[-1.161]$} & {$[0.582]$} & {$[-1.153]$} & [0.643] & {$[0.657]$} & [0.065] & {$[0.652]$} \\
\hline Change of Consumer & -0.102 & 0.012 & -0.001 & 0.036 & 0.002 & 0.036 & 0.000 & -0.009 & 0.003 \\
\hline Confidence & {$[-0.781]$} & {$[0.429]$} & {$[-0.708]$} & {$[1.038]$} & {$[0.170]$} & {$[1.026]$} & {$[0.014]$} & {$[-0.874]$} & {$[0.138]$} \\
\hline Adjusted R-squared & 0.006 & -0.004 & 0.043 & 0.903 & 0.165 & 0.903 & 0.497 & 0.023 & 0.503 \\
\hline $\mathrm{n}$ & 391 & 391 & 391 & 140 & 140 & 140 & 133 & 133 & 133 \\
\hline Akaike info criterion & 2.935 & -0.099 & -6.311 & -0.772 & -2.911 & -9.971 & -0.679 & -2.502 & -9.894 \\
\hline
\end{tabular}

Panel B (Continued):

\begin{tabular}{|c|c|c|c|c|c|c|c|c|c|}
\hline & \multicolumn{3}{|c|}{$\begin{array}{l}\text { (4) Escalation of China-U.S. Trade } \\
\text { Friction (Mar } 8 \text { - Jun 14, 2018) }\end{array}$} & \multicolumn{3}{|c|}{$\begin{array}{l}\text { (5) Further Escalation of China-U.S. } \\
\text { Trade War (Jun } 15 \text { - Nov 30, 2018) }\end{array}$} & \multicolumn{3}{|c|}{$\begin{array}{l}\text { (6) Temporary reprieve (Dec 1, } 2018 \text { till } \\
\text { Mar 31, 2019) }\end{array}$} \\
\hline & $\begin{array}{l}\text { Volatility of } \\
\text { SSE50 (\%) }\end{array}$ & SSE50_UTO & $\begin{array}{l}\text { Volatility of } \\
\text { SSE50 }(\%)\end{array}$ & $\begin{array}{l}\text { Volatility of } \\
\text { SSE50 (\%) }\end{array}$ & SSE50_UTO & $\begin{array}{l}\text { Volatility of } \\
\text { SSE50 }(\%)\end{array}$ & $\begin{array}{l}\text { Volatility of } \\
\text { SSE50 }(\%)\end{array}$ & SSE50_UTO & $\begin{array}{l}\text { Volatility of } \\
\text { SSE50 }(\%)\end{array}$ \\
\hline \multirow[t]{2}{*}{ Intercept } & $1.161 * * *$ & $0.145 * * *$ & $0.993 * * *$ & $1.354 * * *$ & $-0.095^{* *}$ & $1.625 * *$ & $1.472 * * *$ & $-0.009 * *$ & $1.4792 * * *$ \\
\hline & [17.036] & {$[6.408]$} & {$[12.062]$} & [31.892] & {$[-10.404]$} & [34.011] & {$[54.108]$} & {$[-2.197]$} & {$[52.661]$} \\
\hline Opinion Divergence & & & $1.161 * * *$ & & & $2.834 * *$ & & & 0.791 \\
\hline (SSE50_UTO) & & & [3.209] & & & [7.996] & & & [1.030] \\
\hline \multirow[t]{2}{*}{ Trade Friction $(t)$} & $0.390 * * *$ & $-0.104 * *$ & $0.510 * * *$ & 0.087 & $0.139 * * *$ & $-0.305 * * *$ & $-0.149 *$ & $0.076 * * *$ & $-0.209 * *$ \\
\hline & [4.032] & {$[-3.245]$} & {$[5.236]$} & [1.361] & [9.995] & {$[-4.309]$} & {$[-1.737]$} & {$[5.738]$} & {$[-2.016]$} \\
\hline Change 10-year & 8.019 & 1.897 & 5.817 & 3.654 & 1.058 & 0.656 & $10.333 * *$ & 0.651 & $9.818 *$ \\
\hline Bond Yield & [1.149] & [0.818] & [0.890] & [0.692] & [0.928] & {$[0.156]$} & [2.092] & [0.859] & [1.978] \\
\hline$\%$ Change of & 24.477 & -2.589 & $27.483^{* *}$ & 10.305 & 1.866 & 5.017 & -0.717 & 0.144 & -0.831 \\
\hline Exchange Rate & [1.667] & {$[-0.531]$} & [2.007] & [0.789] & {$[0.662]$} & [0.483] & {$[-0.088]$} & [0.115] & {$[-0.102]$} \\
\hline Change of Economic & -1.499 & -0.905 & -0.447 & 0.263 & 0.096 & -0.008 & 0.692 & $0.285^{* *}$ & 0.4664 \\
\hline Prospect & {$[-0.755]$} & {$[-1.374]$} & {$[-0.238]$} & [0.789] & [1.330] & {$[-0.030]$} & [0.798] & [2.145] & {$[0.522]$} \\
\hline Change of Consumer & -0.035 & -0.012 & -0.020 & 0.033 & 0.017 & -0.014 & 0.102 & $0.065 * *$ & 0.050 \\
\hline Confidence & {$[-0.372]$} & {$[-0.402]$} & {$[-0.233]$} & {$[0.311]$} & {$[0.726]$} & {$[-0.167]$} & [0.602] & [2.534] & [0.283] \\
\hline Adjusted R-squared & 0.231 & 0.109 & 0.334 & -0.015 & 0.467 & 0.359 & 0.090 & 0.313 & 0.091 \\
\hline $\mathrm{n}$ & 66 & 66 & 66 & 114 & 114 & 114 & 78 & 78 & 78 \\
\hline Akaike info criterion & 1.003 & -1.203 & 0.872 & 0.696 & -2.371 & 0.245 & -0.125 & -3.875 & -9.324 \\
\hline
\end{tabular}

Note. This table tests the mediation effect of opinion divergence on the "Volatility of SSE50", which is derived using the GARCH model based on daily returns of SSE50, with percentage sign omitted. The proxy of Opinion Divergence, "SSE50_UTO" (unexpected turnover of SSE50), calculated as the daily market-adjusted turnover on day $\mathrm{t}$, where day $\mathrm{t}$ is the investigated day (releasing day of trade friction news), minus the average turnover over the previous 50 days (t-54, t-5). The key explanatory variable "Trade Friction ( $t$ )" is a dummy variable, which equals 1 when any of the People's Daily and the other eight major financial and economic media carries articles on China-US trade friction on day t. "Change of 10-year Bond Yield" equals the 10-year Treasury Bond Yield of the secondary market in day t minus that in day $\mathrm{t}-1$, with percentage sign omitted. "\% Change of Exchange Rate" is the percentage change of the daily exchange rate (direct pricing method), where the positive number represents the depreciation of the RMB, and the percentage sign is omitted. "Change of Economic Prospect" is the "Economic Prospect Index", composed by the Nation Bureau of Statistics, in day t minus that in day t-1, which is orthogonalized to "Change of Consumer Confidence"; "Change of Consumer Confidence" is the "Consumer Confidence Index" in day t minus that in day t-1. Both are extracted from Genius Database. Our sample covered the period from June 16, 2015, to March 31, 2019. *, **, *** denote statistical significance at the 10,5 , and $1 \%$ levels, respectively, using a two-tailed test. 
On the SME market, the effects of trade friction are somewhat different. In Panel A of Table 3, before the Section 301 Investigation, trade friction negatively impacted stock market volatility, whereas the impact is positive after that. For individual stages (Panel B), the coefficients of Trade Friction become insignificant, except for the tenuous positive relation in stage IV.

Table 3. The mediation effect of opinion divergence on the volatility of SME

Panel A:

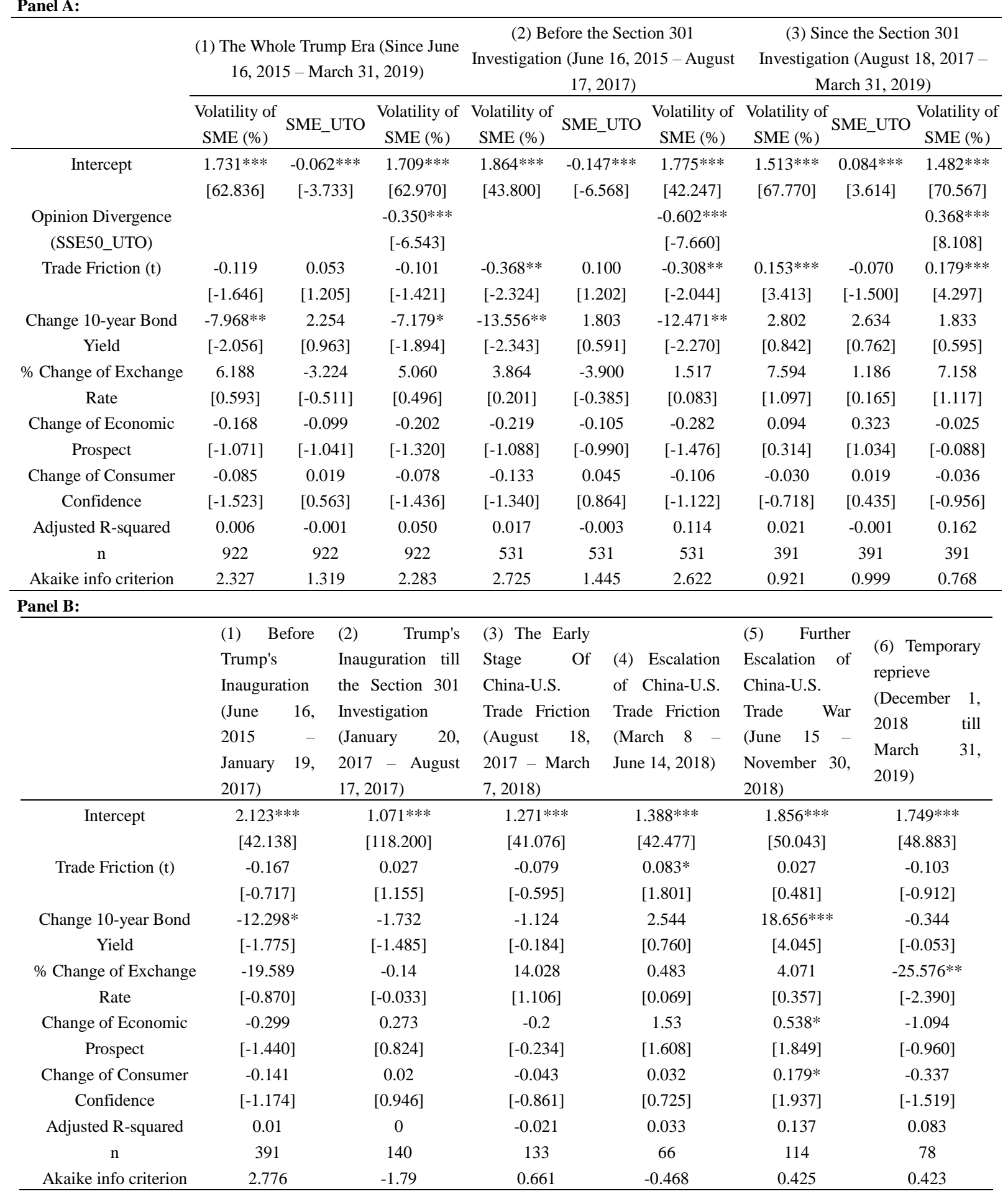


Panel C:

\begin{tabular}{|c|c|c|c|c|c|c|}
\hline & $\begin{array}{l}(1) \quad \text { Before } \\
\text { Trump's } \\
\text { Inauguration } \\
\text { (June 16, 2015 } \\
\text { - January 19, } \\
\text { 2017) }\end{array}$ & $\begin{array}{l}\text { (2) Trump's } \\
\text { Inauguration till } \\
\text { the Section } 301 \\
\text { Investigation } \\
\text { (January 20, } 2017 \\
-\quad \text { August } 17, \\
\text { 2017) }\end{array}$ & $\begin{array}{l}\text { (3) The Early } \\
\text { Stage Of } \\
\text { China-U.S. } \\
\text { Trade Friction } \\
\text { (August 18, } \\
2017 \text { - March } \\
7,2018 \text { ) }\end{array}$ & $\begin{array}{l}\text { (4) Escalation } \\
\text { of China-U.S. } \\
\text { Trade Friction } \\
\text { (March } 8- \\
\text { June 14, 2018) }\end{array}$ & $\begin{array}{l}(5) \quad \text { Further } \\
\text { Escalation of } \\
\text { China-U.S. } \\
\text { Trade War } \\
\text { (June } 15 \quad- \\
\text { November } 30, \\
2018)\end{array}$ & $\begin{array}{lr}\text { (6) Temporary } \\
\text { reprieve } \\
\text { (December } & 1 \text {, } \\
2018 & \text { till } \\
\text { March } & 31, \\
2019) & \end{array}$ \\
\hline Intercept & $\begin{array}{c}2.031 * * * \\
{[38.181]}\end{array}$ & $\begin{array}{l}1.076^{* * * *} \\
{[115.126]}\end{array}$ & $\begin{array}{l}1.265 * * * \\
{[41.776]}\end{array}$ & $\begin{array}{l}1.462 * * * \\
{[44.990]}\end{array}$ & $\begin{array}{l}1.828 * * * \\
{[51.964]}\end{array}$ & $\begin{array}{l}1.621 * * * \\
{[54.223]}\end{array}$ \\
\hline $\begin{array}{l}\text { Opinion Divergence } \\
\text { (SSE50_UTO) }\end{array}$ & $\begin{array}{c}-0.410^{* * *} \\
{[-4.532]}\end{array}$ & $\begin{array}{l}-0.054^{*} \\
{[-1.852]}\end{array}$ & $\begin{array}{c}-0.326 * * * \\
{[-2.647]}\end{array}$ & $\begin{array}{l}0.538^{* *} \\
{[4.620]}\end{array}$ & $\begin{array}{c}0.505 * * * \\
{[4.210]}\end{array}$ & $\begin{array}{c}0.295 * * * \\
{[8.304]}\end{array}$ \\
\hline Trade Friction $(t)$ & $\begin{array}{c}-0.18 \\
{[-0.793]}\end{array}$ & $\begin{array}{c}0.031 \\
{[1.294]}\end{array}$ & $\begin{array}{c}-0.096 \\
{[-0.739]}\end{array}$ & $\begin{array}{c}0.041 \\
{[0.987]}\end{array}$ & $\begin{array}{c}0.025 \\
{[0.474]}\end{array}$ & $\begin{array}{c}0.009 \\
{[0.114]}\end{array}$ \\
\hline $\begin{array}{c}\text { Change 10-year Bond } \\
\text { Yield }\end{array}$ & $\begin{array}{c}-11.960 * \\
{[-1.770]}\end{array}$ & $\begin{array}{c}-1.703 \\
{[-1.473]}\end{array}$ & $\begin{array}{c}-3.154 \\
{[-0.524]}\end{array}$ & $\begin{array}{c}2.713 \\
{[0.938]}\end{array}$ & $\begin{array}{c}14.837 * * * \\
{[3.383]}\end{array}$ & $\begin{array}{c}-3.629 \\
{[-0.776]}\end{array}$ \\
\hline$\%$ Change of Exchange & -19.067 & 0.416 & 13.559 & 3.388 & 4.001 & $-19.443^{* *}$ \\
\hline Rate & {$[-0.868]$} & {$[0.098]$} & [1.094] & {$[0.554]$} & {$[0.377]$} & {$[-2.522]$} \\
\hline $\begin{array}{c}\text { Change of Economic } \\
\text { Prospect }\end{array}$ & $\begin{array}{c}-0.335 \\
{[-1.650]}\end{array}$ & $\begin{array}{c}0.225 \\
{[0.685]}\end{array}$ & $\begin{array}{c}0.113 \\
{[0.134]}\end{array}$ & $\begin{array}{c}1.192 \\
{[1.444]}\end{array}$ & $\begin{array}{c}0.432 \\
{[1.588]}\end{array}$ & $\begin{array}{c}-0.869 \\
{[-1.063]}\end{array}$ \\
\hline Change of Consumer & -0.11 & 0.014 & -0.03 & 0.027 & 0.137 & $-0.269^{*}$ \\
\hline Confidence & {$[-0.936]$} & [0.659] & {$[-0.611]$} & {$[0.707]$} & {$[1.586]$} & {$[-1.689]$} \\
\hline Adjusted R-squared & 0.057 & 0.018 & 0.025 & 0.278 & 0.253 & 0.528 \\
\hline $\mathrm{n}$ & 391 & 140 & 133 & 66 & 114 & 78 \\
\hline Akaike info criterion & 2.729 & -1.801 & 0.622 & -0.747 & 0.29 & -0.23 \\
\hline
\end{tabular}

Note. This table tests the mediation effect of opinion divergence in the regressions on the dependent variable "Volatility of SME", which is derived using the GARCH model based on daily returns of SSE50, with percentage sign omitted. The proxy of Opinion Divergence, "SME_UTO" (unexpected turnover of SSE50), calculated as the daily market-adjusted turnover on day t, where day $\mathrm{t}$ is the investigated day (release date of relevant news), minus the average turnover over the previous 50 days (t-54, $\mathrm{t}-5$ ). The key explanatory variable "Trade Friction ( $t)^{\prime \prime}$ is a dummy variable, which equals 1 when any of the People's Daily and the other eight major financial and economic media carries articles on China-US trade frictions on day t. "Change of 10-year Bond Yield" equals the 10-year Treasury Bond Yield of the secondary market in day t minus that in day $\mathrm{t}-1$, with percentage sign omitted. "\% Change of Exchange Rate" is the percentage change of the daily exchange rate (direct pricing method), where the positive number represents the depreciation of the RMB, and the percentage sign is omitted. "Change of Economic Prospect" is the "Economic Prospect Index", composed by the Nation Bureau of Statistics, in day $t$ minus that in day $\mathrm{t}-1$, which is orthogonalized to "Change of Consumer Confidence"; "Change of Consumer Confidence" is the "Consumer Confidence Index" in day $\mathrm{t}$ minus that in day $\mathrm{t}-1$. Both are extracted from Genius Database. Our sample covered the period from June 16, 2015, to March $31,2019 . * * *, * * *$ denote statistical significance at the 10,5 , and $1 \%$ levels, respectively, using a two-tailed test.

Based on Table 2 and Table 3, we can conclude that trade frictions significantly influenced market volatility. But the effects tend to be different in different markets and at different stages. Therefore, H1 is generally supported in large caps and weakly supported in SMEs' case after the 301 investigation.

\subsection{Mediation Effects of Opinion Divergence}

Table 2 and Table 3 also report the mediation effect of opinion divergence on the stock markets. As shown in Panel A of Table 2, the mediation effects of opinion divergence are significant in the first two regressions. Trade friction significantly increases opinion divergence, and opinion divergence significantly decreases stock volatility in SSE before the Section 301 investigation. It is consistent with Lakonishok, Shleifer, and Vishny (1992), Christie and Huang (1995), and Nofsinger and Sias (1999). Since the coefficients of Trade Friction are still significant when Opinion Divergence is included, opinion divergence plays a partial mediation role in affecting market volatility. This mediation effect becomes positive and weaker in the second sub-period (after the 301 investigation). But when we look at individual stages, in Stages IV and V (Panel B), the mediation effect of opinion divergence on market volatility is significant, shown with the positive coefficients of Opinion Divergence. Therefore, we can say there is a mediation effect of opinion divergence for the large caps (SSE50), although it takes different forms under different circumstances. So, $\mathrm{H} 2$ and $\mathrm{H} 3$ are generally supported.

There is generally no mediation effect for the SME firms (see Table 3), for Opinion Divergence is not related to Trade Friction. Therefore, in the case of SME, neither $\mathrm{H} 2$ nor $\mathrm{H} 3$ is supported. However, Opinion Divergence 
significantly influences stock volatility (see Panel C). As with SSE50, it is negative before the Section 301 investigation and positive after it. When we look at different stages, the coefficients of Opinion Divergence are still significant in each stage, consistent with Panel A.

\subsection{Further Discussion}

Both Table 2 and Table 3 show that Opinion Divergence decreases market volatility before Section 301 Investigation whereas increases market volatility afterward. However, it might be of concern that Opinion Divergence is endogenously determined by stock market volatility. Firstly, excess volatility increased uncertainties that investors perceived, and investors tended to hold different opinions about the future. Secondly, investors' beliefs and market volatility might be simultaneously influenced by some unobservable factors. To solve the endogeneity problem of opinion divergence, we use stock return as an instrument variable, and two-stage least square (2SLS) regression was adopted.

Table 4. 2SLS regressions: dealing with the endogeneity of opinion divergence in SSE

\section{Panel A: 2SLS Regressions: Before the 301 Investigation}

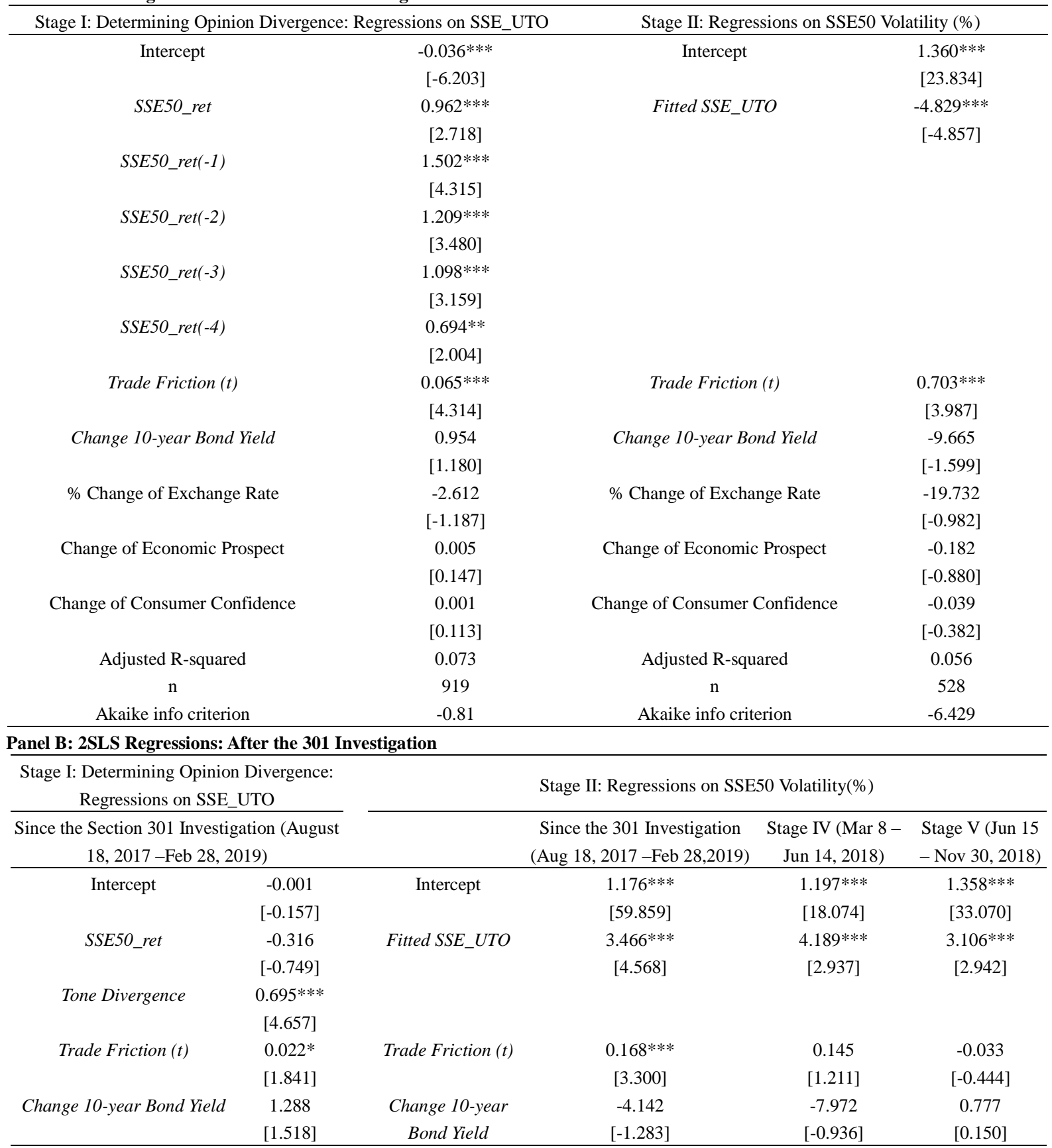




\begin{tabular}{|c|c|c|c|c|c|}
\hline$\%$ Change of Exchange Rate & $\begin{array}{c}-4.286^{* *} \\
{[-2.442]}\end{array}$ & $\begin{array}{c}\% \text { Change of } \\
\text { Exchange Rate }\end{array}$ & $\begin{array}{c}27.326^{* * * *} \\
{[4.096]}\end{array}$ & $\begin{array}{c}45.617 \text { *** } \\
{[2.899]}\end{array}$ & $\begin{array}{l}16.834 \\
{[1.314]}\end{array}$ \\
\hline Change of Economic & 0.059 & Change of & -0.006 & -1.151 & 0.014 \\
\hline Prospect & {$[0.801]$} & Economic Prospect & {$[-0.021]$} & {$[-0.585]$} & [0.040] \\
\hline Change of Consumer & -0.002 & Change of Consumer & -0.01 & 0.001 & 0.043 \\
\hline Confidence & {$[-0.198]$} & Confidence & {$[-0.263]$} & {$[0.006]$} & [0.423] \\
\hline Adjusted R-squared & 0.097 & Adjusted R-squared & 0.175 & 0.279 & 0.052 \\
\hline $\mathrm{n}$ & 391 & $\mathrm{n}$ & 391 & 67 & 114 \\
\hline Akaike info criterion & -1.875 & Akaike info criterion & -8.544 & -8.219 & -8.575 \\
\hline
\end{tabular}

Note. To deal with the endogeneity of Opinion Divergence (SSE_UTO), 2SLS was adopted, and the results are reported in this table. In Panel A, The market return (SSE_ret) (with its lags) is used as an instrument variable. Tone Divergence is adopted as an additional instrumental variable. It equals the highest tone minus the lowest tone within one day if there is more than one piece of news in the same day, and 0 otherwise. The "Trade Friction ( $t$ )" is a dummy variable, which equals 1 when any of the People's Daily and the other eight major financial and economic media carries articles on China-US trade friction on day t. "Change of 10-year Bond Yield" equals the 10-year Treasury Bond Yield of the secondary market in day $\mathrm{t}$ minus that in day $\mathrm{t}-1$, with percentage sign omitted. "\% Change of Exchange Rate" is the percentage change of the daily exchange rate (direct pricing method), where the positive number represents the depreciation of the RMB, and the percentage sign is omitted. "Change of Economic Prospect" is the "Economic Prospect Index", composed by the Nation Bureau of Statistics, in day $\mathrm{t}$ minus that in day $\mathrm{t}-1$, which is orthogonalized to "Change of Consumer Confidence"; "Change of Consumer Confidence" is the "Consumer Confidence Index" in day t minus that in day t-1. Both are extracted from Genius Database. Our sample covered the period from June 16, 2015, to March 31, 2019. *,**, *** denote statistical significance at the 10, 5, and 1\% levels, respectively, using a two-tailed test.

For SSE50, as shown in Panel A of Table 4, the Opinion Divergence is regressed on SSE50 return with its lags and other determinants first. Then the volatility of SSE50 is regressed on the fitted value of Opinion Divergence. Consistent with Panel A of Table 2, we find that Opinion Divergence played an important role in reducing the stock volatility before the 301 investigation. In Panel B of Table 4, we add another instrument variable, Tone Divergence, to capture the difference in news releasing stances on the same day (Note 16). The rationale here is that if the news released from different resources on the same day shows a large difference in attitude, investors reading the news will be more likely to have different opinions. Tone Divergence equals the highest tone (Note 17) minus the lowest tone within one day if there is more than one piece of news in one day, and 0 if otherwise. Panel B shows that Tone Divergence significantly increased Opinion Divergence. The fitted value of Opinion Divergence significantly increased stock market volatility after the section 301 investigation, and in stage IV and stage V, respectively, which is consistent with the mediation effects of Opinion Divergence, as shown in Table 2. Therefore, Table 4 shows that opinion divergence was an important factor influencing market volatility after controlling the endogeneity problem of opinion divergence, consistent with Table 2.

\section{Conclusion}

China-US relations is one of the most important bilateral relations in the world. "Trade and economic relations between China and the United States are of great significance for the two countries as well as for the stability and development of the world economy." (Note 18) One-fifth of Chinese products are sold to the U.S., and 22\% of total American imports come from China. However, with the rapid development and the corresponding expansion of China's national interests since the beginning of the 21 st century, the natural conflict between rising and established powers is inevitable.

This research aims to disentangle the relation between trade frictions, opinion divergence, and Chinese stock market reactions during the Trump era. Specifically, we find trade friction news from the state-controlled media was already magnifying its importance and was enough to disturb investors' nerves. Trade frictions significantly influenced the market volatility, and this effect tends to differ for different types of stocks. H1 is generally supported in the case of large caps. But in the case of SMEs, the result is complex and H1 partially supported after the 301 investigation.

For the big caps (SSE50), trade frictions lead to higher opinion divergence, and opinion divergence reduces market volatility before the 301 investigation, and increases market volatility in Stages IV and V. So, opinion divergence plays a partial mediation role in affecting market volatility. $\mathrm{H} 2$ and $\mathrm{H} 3$ are generally supported by large caps. For small caps (SME), opinion divergence is not related to trade friction, and there is no mediation effect of it. Neither $\mathrm{H} 2$ nor $\mathrm{H} 3$ is supported. However, opinion divergence significantly influences stock volatility, negative before the section 301 investigation and positive after it.

2SLS regressions have been conducted to handle the endogeneity of opinion divergence for large caps. The fitted 
opinion divergence still played an important role in influencing market volatility (Note 19), further supporting $\mathrm{H} 2$ and $\mathrm{H} 3$ for SSE 50.

Overall, in the case of SSE50, all three hypotheses are generally supported. Although there is no mediation effect of opinion divergence in affecting the stock volatilities, it still plays a significant role by itself after controlling its endogeneity.

\section{Acknowledgments}

We are grateful for the financial support from the Central Universities Fundamental Research Funds for Pre-research Project ("The China-U.S. trade frictions, investor sentiment, and market stock volatility", Project No. 3162018ZYE05).

\section{References}

Arin, K. P., Ciferri, D., \& Spagnolo, N. (2008). The price of terror: The effects of terrorism on stock market returns and volatility. Economics Letters, 101(3), 164-167. https://doi.org/10.1016/j.econlet.2008.07.007

Barberis, N., Shleifer, A., \& Vishny R. (1998). A model of investor sentiment. Journal of Financial Economics, 49, 307-343. https://doi.org/10.3386/w5926

Baron, R. M., \& Kenny, D. A. (1986). The moderator-mediator variable distinction in social psychological research: conceptual, strategic, and statistical considerations. Journal of Personality and Social Psychology, 51(6), 1173-1182. https://doi.org/10.1037/0022-3514.51.6.1173

Besley, T., \& Prat, A. (2006). Handcuffs for the grabbing hand? Media capture and government accountability. American Economic Review, 96, 720-736. https://doi.org/10.1257/aer.96.3.720

Cao, M., \& Wei, J. (2005). Stock market returns: a note on temperature anomaly. Journal of Banking and Finance, 29, 1559-1573. https://doi.org/10.1016/j.jbankfin.2004.06.028

Capelle-Blancard, G., \& Laguna M. A. (2010). How does the stock market respond to chemical disasters?. Journal of Environmental Economics and Management, 59(2), 0-205. https://doi.org/10.1016/j.jeem.2009.11.002

Chang, E. C., Cheng, J. W., \& Yu, Y. (2007). Short-sales constraints and price discovery: Evidence from the Hong Kong market. The Journal of Finance, 62(5), 2097-2121. https://doi.org/10.1111/j.1540-6261.2007.01270.x

Christie, W., \& Huang, R. (1995). Following the pied piper: Do individual returns herd around the market? Financial Analyst Journal, July-August, 31-37. https://doi.org/10.2469/faj.v51.n4.1918

Crabbe, L., \& Post, M. A. (1994). The effect of a rating downgrade on outstanding commercial paper. Journal of Finance, 46, 39-56. https://doi.org/10.1111/j.1540-6261.1994.tb04419.x

DeLong, J., Shleifer, A., Summers, L., \& Waldmann, R. (1990). Noise trader risk in financial markets. Journal of Political Economy, 98, 703-738.

Demirkan, S. (2012) Volume, opinion divergence and book-to-market anomaly. Journal of Knowledge Globalization, 5(1), 29-45.

Djankov, S., McLiesh, C., Nenova, T., \& Shleifer, A. (2003). Who owns the media? Journal of Law and Economics, 46, 341-381. https://doi.org/10.1086/377116

Duchin, R., \& Levy, M. (2010). Disagreement, portfolio optimization and excess volatility. Journal of Financial and Quantitative Analysis, 45, 623-640. https://doi.org/10.1017/s0022109010000189

Dyck, A., Moss, D., \& Zingales, L. (2013). Media versus special interests. Journal of Law and Economics, 56, 521-553. https://doi.org/10.1086/673216

Edmans, A., Garcia, D., \& Norli, Ø. (2007). Sports sentiment and stock returns. Journal of Finance, 62, 1967-1998. https://doi.org/10.1111/j.1540-6261.2007.01262.x

Eun, C., \& Resnick, B. (1984). Estimating the correlation structure of international share prices. Journal of Finance, 39, 1311-1324. https://doi.org/10.1111/j.1540-6261.1984.tb04909.x

Garfinkel, J. A., \& Sokobin J. (2006). Volume, opinion divergence, and returns: A study of post-earnings announcement drift. Journal of Accounting Research, 44(1), 85-112. https://doi.org/10.1111/j.1475-679x.2006.00193.x

Goetzmann, W., Kim, D., Kumar, A., \& Wang, Q. (2015). Weather-induced mood, institutional investors and 
stock returns. Review of Financial Studies, 28, 73-111. https://doi.org/10.1093/rfs/hhu063

Greenspan, A. (2007). The Age of Turbulence: Adventures in a New World (p. 14). New York: Penguin Press. https://doi.org/10.1163/2468-1733_shafr_sim280020428

Henson, S., \& Mazzocchi, M. (2002). Impact of Bovine Spongiform Encephalopathy on Agribusiness in the United Kingdom: Results of an Event Study of Equity Prices. American Journal of Agricultural Economics, 84(2). https://doi.org/10.1111/1467-8276.00304

Hirshleifer, D., \& Shumway, T. (2003). Good day sunshine: stock returns and the weather. Journal of Finance, 58, 1009-1032. https://doi.org/10.1111/1540-6261.00556

Hong, H., \& Stein, J. C. (1999). A unified theory of underreaction, momentum trading, and overreaction in asset markets. Journal of Finance, 54, 2143-2184. https://doi.org/10.1111/0022-1082.00184

Hong, H., \& Stein, J. C. (2007). Disagreement and the stock market. Journal of Economic Perspectives, 21(2), 109-128. https://doi.org/10.1257/jep.21.2.109

Houston, J. F., Lin, C., \& Ma, Y. (2011). Media ownership, concentration and corruption in bank lending. Journal of Financial Economics, 100, 326-350. https://doi.org/10.1016/j.jfineco.2010.12.003

Humpe, A., \& Macmillan P. (2009). Can macroeconomic variables explain long-term stock market movements? A comparison of the U.S. and Japan. Applied Financial Economics, 19(2), 111-119. https://doi.org/10.1080/09603100701748956

Illeditsch, P. K. (2011). Ambiguous information, portfolio inertia, and excess volatility. Journal of Finance, 66(6), 2213-2247. https://doi.org/10.1111/j.1540-6261.2011.01693.x

Jones, C. M., \& Lamont, O. A. (2002). Short-sale constraints and stock returns. Journal of Financial Economics, 66(2), 207-239. https://doi.org/10.1016/s0304-405x(02)00224-6

Kaplanski, G., \& Levy, H. (2010). Sentiment and stock prices: the case of aviation disasters. Journal of Financial Economics, 95, 174-201. https://doi.org/10.1016/j.jfineco.2009.10.002

Karlekar, K. D., \& Dunham, J. (2014). Press freedom in 2013: media freedom hits decade low. Freedom House Report. Retrieved from http://freedomhouse.org/sites/default/files/FOTP_2014.pdf

Kollias, C., Manou, E., Papadamou, S., \& Stagiannis, A. (2011). Stock markets and terrorist attacks: Comparative evidence from a large and a small-capitalization market. European Journal of Political Economy, 27 (supp-S1), S64-S77. https://doi.org/10.1016/j.ejpoleco.2011.05.002

Lakonishok, J., Shleifer, A., \& Vishny, R. (1992). The impact of institutional trading on stock prices. Journal of Financial Economics, 32, 23-43. https://doi.org/10.1016/0304-405x(92)90023-q

Lamla, M. J., \& Maag, T. (2012). The role of media for inflation forecast disagreement of households and professional forecasters. Journal of Money, Credit and Banking, 44(7), 1325-1350. https://doi.org/10.1111/j.1538-4616.2012.00534.x

Li, P. G., \& Shen, Y. F. (2010). The corporate governance role of media: Empirical evidence of China. Economic Research Journal, 4, 14-27.

Lopatta, K., \& Kaspereit, T. (2014). The cross-section of returns, benchmark model parameters, and idiosyncratic volatility of the world's nuclear energy firms after Fukushima Daiichi. Energy Economics, 4l(1), 125-136. https://doi.org/10.1016/j.eneco.2013.10.006

Loughran, T., \& McDonald, B. (2011). When is a Liability not a Liability? Textual Analysis Dictionaries and 10-Ks. Journal of Finance, 66(1), 35-65. https://doi.org/10.1111/j.1540-6261.2010.01625.x

Maysami, R. C., \& Koh, T. S. (2000). A vector error correction model for the Singapore stock market. International Review of Economics and Finance, 9, 79-96. https://doi.org/10.1016/s1059-0560(99)00042-8

Miller, E., \& Risk, M. (1977). Uncertainty and divergence of opinion. The Journal of Finance, 32(04), 1151-1168. https://doi.org/10.1111/j.1540-6261.1977.tb03317.x

Mukherjee, T. K., \& Naka, A. (1995). Dynamic relations between macroeconomic variables and the Japanese stock market: An application of a vector error correction model. Journal of Financial Research, 18, 223-237. https://doi.org/10.1111/j.1475-6803.1995.tb00563.x

Navarro, P., \& Ross, W. (2016). Scoring the Trump economic plan: Trade, regulatory \& energy policy impacts. White paper. Retrieved from https://assets.donaldjtrump.com/Trump_Economic_Plan.pdf 
Nikkinen, J., \& Sahlström, P. (2004). Scheduled domestic and U.S. macroeconomic news and stock valuation in Europe. Journal of Multinational Financial Management, 14(3), 201-215. https://doi.org/10.1016/j.mulfin.2003.01.001

Nofsinger, J., \& Sias, R. (1999). Herding and feedback trading by institutional and individual investors. Journal of Finance, 54, 2263-2295. https://doi.org/10.1111/0022-1082.00188

Peress, J. (2014). The media and the diffusion of information in financial markets: Evidence from newspaper strikes. The Journal of Finance, 69(5), 2007-2043. https://doi.org/10.1111/jofi.12179

Ramiah V., \& Graham M. (2013). The impact of domestic and international terrorism on equity markets: Evidence from Indonesia. International Journal of Accounting \& Information Management, 21(1), 91-107.

Ross, S. A. (1976). Return, risk, and arbitrage. In I. Friend, \& J. Bicksler (Eds.), Risk and Return in Finance. Ballinger, MA: Cambridge. https://doi.org/10.1108/18347641311299768

Scholtens B., \& Voorhorst Y. (2013). The impact of earthquakes on the domestic stock market. Earthquake Spectra, 29(1), 325-337. https://doi.org/10.1193/1.4000103

Shalen, C. T. (1993). Volume, volatility, and the dispersion of beliefs. Review of Financial Studies, 6(2), 405-434. https://doi.org/10.1093/rfs/6.2.405

Sharp, W. F. (1964). Capital asset price: A theory of market equilibrium under conditions of risk. Journal of Finance, 19, 425-442. https://doi.org/10.2307/2977928

Shiller, R. J. (2005). Irrational Exuberance. Princeton. NJ: Princeton University Press.

Shleifer, A., \& Vishny, R. (1997). The limits of arbitrage. Journal of Finance, 52, 35-55. https://doi.org/10.1111/j.1540-6261.1997.tb03807.x

Tetlock, P. C., Saar-Tsechansky, M., \& Macskassy, S. (2008). More than words: Quantifying language to measure firms' fundamentals. Journal of Finance, 63(3), 1437-1467. https://doi.org/10.1111/j.1540-6261.2008.01362.x

Wang, C. Y., \& Wu, J.W. (2015). Media tone, investor sentiment and IPO pricing. Journal of Financial Research, (9), 174-189.

Yardeni, E. (1997). Fed's stock market model finds overvaluation. US Equity Research, Deutsche Morgan Grenfell.

Yardeni, E. (1999). New, improved stock valuation model. US Equity Research, Deutsche Morgan Grenfell.

You, J. X., \& Wu, J., (2012). Spiral of silence: media sentiment and the asset mispricing. Economic Research Journal, 7, 141-152.

You, J., Zhang, B., \& Zhang, L. (2018). Who captures the power of the pen? Review of Financial Studies, 31(1), 43-96. https://doi.org/10.1093/rfs/hhx055

Zhang, W., \& Du. J. (2020). State-controlled media tone, China-U.S. trade frictions, and stock market reactions. Working paper.

\section{Notes}

Note 1. Mainly about terrorist attacks, for example, Nikkinen and Sahlström (2004); Arin, Ciferri and Spagnolo, (2008); Kollias, Manou, Papadamou, and Stagiannis (2011); Ramiah and Graham, (2013).

Note 2. Such as earthquakes (Scholtens \& Voorhorst, 2013) and disease infections (Henson \& Mazzocchi, 2002).

Note 3. Such as explosions in chemical plants and oil refineries (Capelle-Blancard \& Laguna, 2010), aviation disasters (Kaplanski \& Levy, 2010), nuclear leakage accident (Lopatta \& Kaspereit, 2014).

Note 4. The United States used "Special 301" to carry out "Special 301 Investigation" on Chinese intellectual property rights three times, which began in April 1991, June 1994, and April 1996 and lasted for 9, 8, and 2 months, respectively. Three agreements on intellectual property rights were signed. In addition to the intellectual property rights investigation, a "301 Investigation" on market access was launched in October 1991 and lasted for 12 months, which aimed at the unfair barriers China has imposed on American goods entering the Chinese market, and an agreement was reached in 1992. In October 2010, the United States launched "301 Investigation" on China's clean energy policies and finally reached an agreement through negotiations. On August 18, 2017, the U.S. Trade Representative Office officially launched the sixth 301 investigations into China, which was focused 
on legal policies or practices related to technology transfer, intellectual property rights, and innovations.

Note 5. Allison coined the phrase Thucydides Trap to refer to when a rising power causes fear in an established power, which escalates toward war. See, https://en.wikipedia.org/wiki/Graham_T._Allison\#Thucydides_Trap

Note 6. Speaking on the Piers Morgan Tonight talk show in February 2011 about "what a President Trump would do to revive America's prosperity", in responding to Piers Morgan's questions about how to deal with the Chinese and whether they are Americans' friends, Donald Trump said, "I don't think they're friends. I think they're enemies. We have very, very unfair trade. I call it unfair trade. I would tax them 25 percent. They would come to the table immediately." Refer to the CNN website (February 9, 2011), http://transcripts.cnn.com/TRANSCRIPTS/1102/09/pmt.01.html

Note 7. Refer to the website of Politico (November 10, 2015), https://www.politico.com/story/2015/11/donald-trump-china-currency-manipulation-215679

Note 8. Refer to New York Times (January 6, 2016), https://www.nytimes.com/politics/first-draft/2016/01/07/donald-trump-says-he-favors-big-tariffs-on-chinese-exp orts/

Note 9. The global economic growth has slowed from 3.5\% in 2017 to $2.2 \%$ in 2019, with China contributing about $1 / 3$ of the growth.

Note

10.

See, https://business.financialpost.com/pmn/business-pmn/trumps-tariffs-what-they-are-and-how-china-is-responding

Note 11. Refer to "Trump hails trade deal with China as one of the largest ever made" from the CNBC website, see https://www.cnbc.com/2018/12/02/trump-hails-trade-deal-with-china-as-one-of-the-largest-ever-made.html More details about what happened during this stage can be found on https://en.wikipedia.org/wiki/Presidency_of_Donald_Trump\#cite_note-314

Note 12. It includes Shanghai Securities Daily, China Securities Daily, Securities Times, Financial Times, Economic Daily, China Reform Daily, China Daily, and Stock Market Weekly.

Note 13. The second measure of the unexpected volume is designed to control both the liquidity effect and informing effect in volume (Garfinkel \& Sokobin, 2006; Demirkan, 2012). Similar to Crabbe and Post (1994), Garfinkel and Sokobin (2006), and Demirkan (2012), who adopted the standardized unexpected volume (SUV), we estimated the volume attributable to differences of opinion using a methodology that mirrors the market model approach to estimate abnormal returns. Specifically, we constructed a measure of unexpected turnover $(U T O)$, calculated as a prediction error from a univariate turnover model on the absolute value of returns for the news release on day t. In this paper, we only present the empirical results based on the first proxy, for we get similar results when we use the second proxy for opinion divergence.

Note 14. The historical data of the 10-year bond yield rate was extracted from https://cn.investing.com/rates-bonds/china-10-year-bond-yield-historical-data

Note 15. The historical data of the exchange rate was extracted from https://cn.investing.com/currencies/usd-cny-historical-data/

Note 16. Because there are only a few news pieces related to China-US trade before the section 301 investigation, with the majority released after that, it's impossible to calculate Tone Divergence of news before the section 301 investigation. So, we only conducted 2SLS with Tone Divergence as an instrument after the 301 investigation.

Note 17. This is the media tone of the news, which is calculated following Tetlock, Saar-Tsechansky, and Macskassy (2008), Loughran and McDonald (2011), Wang and Wu (2015), and Zhang and Du (2021). The details are omitted here and available upon request.

Note 18. The Facts and China's Position on China-US Trade Friction (September 24, 2018), see http://www.xinhuanet.com/politics/2018-09/24/c_1123475262.htm (Chinese)

Note 19. When we conduct similar tests for SMEs, the fitted value of opinion divergence still significantly influences stock volatilities. Since there is no mediation effect of opinion divergence for SMEs (as shown in table 3), I don't report the result for SMEs, and it is available upon request.

Note 20. Refer to the website of NPR, see https://www.npr.org/2018/03/08/591744195/trump-expected-to-formally-order-tariffs-on-steel-aluminum-imports

Note 21. Refer to the website of NPR, see https://www.npr.org/2018/03/08/591744195/trump-expected-to-formally-order-tariffs-on-steel-aluminum-imports 
Note 22. See

https://business.financialpost.com/pmn/business-pmn/trumps-tariffs-what-they-are-and-how-china-is-responding

Note 23. Refer to "Trump hails trade deal with China as one of the largest ever made" from CNBC website, see https://www.cnbc.com/2018/12/02/trump-hails-trade-deal-with-china-as-one-of-the-largest-ever-made.html.

More details about what happened during this stage can be found on https://en.wikipedia.org/wiki/Presidency_of_Donald_Trump\#cite_note-314

Note 24. See

https://www.China-USfocus.com/finance-economy/china-us-relations-should-be-reshaped-through-trade-war-andnegotiations.

\section{Appendix A:}

\section{Specifications about Sub-sample Periods During the Trump Era}

Stage I (before Trump's inauguration): June 16, 2015, till January 19, 2017

From Donald Trump's announcement of his candidacy for President of the United States (June 16, 2015) till before his inauguration (January 19, 2017)

Stage II (before the 301 investigation): January 20, 2017, till August 17, 2017

From Donald Trump's inauguration (January 20, 2017) till before U.S Trade Representative (USTR) formally initiated an investigation of China under Section 301 of the Trade Act of 1974 on August 18, 2017.

Stage III (301 investigation period): August 18, 2017, till March 7, 2018

From the initiation of the U.S.'s 301 investigation of China (August 18, 2017) to Trump formally orders tariffs on steel and aluminum imports on March 8, 2018 (Note 20).

Stage IV (Early stage of China-U.S. trade war): March 8, 2018, till June 14, 2018

From Trump's formally ordering tariffs on steel, aluminum imports on March 8, 2018 (Note 21), till the release of a $\$ 34$ billion list of Chinese goods to face tariff by Trump on June 15, 2018 (Note 22). On June 15, Donald Trump released a list of $\$ 34$ billion of Chinese goods to face a $25 \%$ tariff, starting on July 6 . Another list with $\$ 16$ billion of Chinese goods was released, with an implementation date of August 23.

Stage V (further escalation of China-U.S. trade war and China's retaliation): June 15, 2018, till November 30,2018

From the release of a \$34 billion list of Chinese goods to face tariffs on June 15, 2018, till Trump and Chinese President Xi Jinping agreed on a temporary stop to their bilateral trade disagreement on December 1, 2018 (Note 23).

Stage VI (reprieve): December 1, 2018, till March 31, 2019

From Trump and President Xi's agreement on a temporary stop to their bilateral trade disagreement on December 1, 2018, till March 31, 2019.

Seven rounds of high-level economic negotiations have been held since February 2018. An important turning point in the China-US trade war occurred during the G20 Summit in December last year, when the two heads of state reached an agreement for a ninety-day 'truce'. The agreement and "the high frequency of close consultations suggest that the trade war is in the critical final stage" (Note 24).

\section{Copyrights}

Copyright for this article is retained by the author(s), with first publication rights granted to the journal.

This is an open-access article distributed under the terms and conditions of the Creative Commons Attribution license (http://creativecommons.org/licenses/by/4.0/). 